\title{
UNPACKING THE TPACK FRAMEWORK IN EFL CONTEXT: A REVIEW OF EMPIRICAL STUDIES FROM 2015 TO 2019
}

\author{
Shelia Anjarani \\ Universitas Muhammadiyah Purwokerto, Purwokerto, Indonesia \\ shelia.anjarani@gmail.com
}

\begin{abstract}
Technological Pedagogical Content Knowledge (TPACK) has been implemented as a conceptual framework for the knowledge domains that teachers need to master to successfully teach using technology and it has attracted a lot of attention across the field of education. Nonetheless, the framework has been criticized for not being practically useful. TPACK studies were mostly conducted in Mathematics and Science. Meanwhile, research on integrating English as a foreign language (EFL) into TPACK has been lagging behind. To better understand the critics, an investigation of general characteristics of TPACK studies in EFL context is needed. This paper is a systematic literature review of 20 peer-reviewed journal articles concerning the use of TPACK in EFL context published from 2015 to 2019.
\end{abstract}

Keywords: EFL, teachers, TPACK

\section{INTRODUCTION}

Mastering pedagogy and content knowledge were enough for teachers in the past, but in this digital era, teachers must not only master pedagogy and content knowledge, but also technology competence. The use of technology in English language teaching is snowballing. It is driven by a belief that technology can improve the learning outcomes (Selwyn, 2012). Moreover, technology has a positive effect on students' learning when it is properly integrated (Schrum et al., 2007). In the other hand, Lei (2009) stated that being able to master the technology does not mean that being able to implement technology critically, wisely, and meaningfully in the classroom. According to Mishra and Koehler (2006), teachers only explore about technology and not how to implement it into teaching and learning process. Thus, the use of technology in education requires the knowledge and understanding of English teachers. Meanwhile, there are some stumbling blocks about the use and integration of technology in education. Research mentioned that college teachers are well equipped with the content knowledge in their subject areas, but they often lack pedagogical skills in integrating technology (Clarke and Hollingsworth, 2002; Jang and Chen, 
2010). Thus, there is an evident need for the teachers to understand technology, pedagogy, and content knowledge in English language teaching. Technology can no longer be separated from pedagogical and content knowledge that teachers need to acquire. To address this issue, Mishra and Koehler (2006) suggested a structure for technological pedagogical content knowledge (TPACK) that includes theoretical frameworks that can be used to help teachers carry out self-assessments and to understand the growth of their professional knowledge through technology-based teaching practices.

Around fifty years ago, Shulman (1986) conducted a research program "Knowledge Growth for Teaching" which was about the disparity of teachers. TPACK is the development of Shulman's concept about Pedagogical Content Knowledge (PCK) model (Shulman, 1986). Then, the technological aspect was added by Koehler and Mishra (2005) which refers to the knowledge about how to use and integrate technological resources.

There are three categories of knowledge each teacher should flourish to grow in the minds: (a) subject matter content knowledge, (b) pedagogical content knowledge, (c) curricular knowledge (Shulman, 1986). Subject matter content knowledge refers to the knowledge of the ideas. Pedagogical content knowledge involves the content of teaching and the ways it is presented. Curricular knowledge relates to the curriculum designed for a subject and pedagogy matter. Those three notions of knowledge categories have been permeated in teacher education since 1987 (Shulman, 1986; Mishra \& Koehler, 2006).

TPACK is introduced as a framework for the understanding of teacher skills needed for technology integration (Mishra \& Koehler, 2006). There are seven sub-domains in TPACK (Mishra \& Koehler, 2006):

1) Content knowledge (CK) refers to knowledge about subject matter

2) Technology knowledge (TK) refers to knowledge about various technologies

3) Pedagogical knowledge (PK) refers to knowledge about methods of teaching

4) Technological content knowledge (TCK) refers to knowledge about subject matter presented by using technology

5) Technological pedagogical knowledge (TPK) refers to knowledge about the use of technology to implement different teaching methods

6) Pedagogical content knowledge (PCK) refers to knowledge of teaching methods for different types of subject matter

7) Technological pedagogical content knowledge (TPACK), which is understood as knowledge of the use of technology to implement teaching methods for different types of subject matter

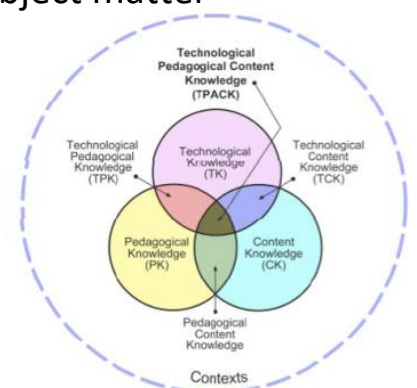

Figure 1. The TPACK Framework (Mishra \& Koehler, 2006) 
TPACK relates to the knowledge base that teachers need to integrate technology. One aspect of knowledge base needs teachers to identify and actualize the affordances of a specific technology (Koehler \& Mishra, 2008). Affordances refer to how technology is meaningful and beneficial to its users. Teachers need to gain a deep understanding of technological affordances in an educational context in order to help students learn with technology critically. How the TPACK framework contributes to teacher research on technology integration is to highlight teachers' capacity to juggle technological, pedagogical, and content knowledge. Teachers should focus more on what to teach with particular technology tools rather than how to teach with the tools (Hofer \& Harris, 2012). Here we see that TPACK is considered ideal for English teachers to acquire. TPACK gives insight framework in teaching and learning process. Meanwhile, there is not clear understanding how to integrate TPACK in teaching and learning process. In the other hand, TPACK has attracted much attention in research as evidenced by more than 600 journal articles using TPACK framework in many fields of education (Koehler, Mishra, Kereluik, Shin, \& Graham, 2014). Mishra \& Koehler (2006) state that the great impact of TPACK may be because it constitutes a theoretical framework that focuses on how technology is integrated into teaching by suggesting a holistic view of the entire knowledge base teachers need to master to effectively apply technology in teaching. They explained that it is about teachers incorporating technological knowledge into the structure of pedagogical content knowledge and the surrounding context. In the previous study, Chai et al. (2013) involved 74 articles exploring the site of the studies, publication outlet, method, and teachers' and researcher's design in their program using TPACK framework. Another study was conducted by Voogt et al. (2013). Their review investigated the theoretical basis and practical use of TPACK. Those previous studies were systematic review about TPACK in various subjects. Though it draws the attention from the increasing number of studies related to TPACK, there is not yet a systematic review about TPACK in EFL context. Thus, systematic review of TPACK in EFL context is called for. Moreover, there is a need to identify how TPACK is identified in English teaching and learning process. The purpose of this paper is to review some studies about TPACK in EFL context from 2015 to 2019 and how TPACK framework is identified in English language teaching context. Therefore, I posed these following questions: (1) What are the general characteristics of TPACK paper in EFL context? and (2) How is the teacher TPACK identified in EFL context?.

\section{General Characteristics}

In order to categorize and analyze general characteristics of TPACK articles in EFL context, a protocol was developed. There are some points included in the protocol, such as author(s) and year of paper publication, the journals, research methodologies (quantitative method, qualitative method, and mixed method), and the 
Vol. 2 No. 2

December 2020

e- ISSN 2685 - 0559

p- ISSN 2684 - 673X

study objects (pre-service teachers or articles are presented in the table in-service teachers). The reviewed below.

An overview of the reviewed articles is presented in Table 1.

\begin{tabular}{|c|c|c|c|c|c|c|}
\hline Author(s) & Journals & $\begin{array}{l}\text { Qualitative } \\
\text { Method }\end{array}$ & $\begin{array}{l}\text { Quantitative } \\
\text { Method }\end{array}$ & $\begin{array}{l}\text { Mixed } \\
\text { Method }\end{array}$ & $\begin{array}{l}\text { Pre-service } \\
\text { teachers }\end{array}$ & $\begin{array}{l}\text { In-service } \\
\text { teachers }\end{array}$ \\
\hline Baser et al. (2015) & $\begin{array}{l}\text { Computer Assisted } \\
\text { Language Learning }\end{array}$ & & & $\mathrm{x}$ & $x$ & \\
\hline Mahdum (2015) & $\begin{array}{l}\text { Mediterranean } \\
\text { Journal of Social } \\
\text { Sciences }\end{array}$ & & $x$ & & & $x$ \\
\hline Oz (2015) & $\begin{array}{l}\text { International } \\
\text { Education Studies }\end{array}$ & & & $x$ & $\mathrm{x}$ & \\
\hline Tseng (2015) & $\begin{array}{l}\text { International } \\
\text { Journal on Digital } \\
\text { Learning Technology }\end{array}$ & & & $x$ & & $x$ \\
\hline Wu \& Wang (2015) & $\begin{array}{l}\text { The Asia-Pacific } \\
\text { Education } \\
\text { Researcher }\end{array}$ & & $\mathrm{x}$ & & & $x$ \\
\hline Ansyari (2015) & $\begin{array}{l}\text { Australasian Journal } \\
\text { of } \\
\text { Educational } \\
\text { Technology }\end{array}$ & & & $\mathrm{x}$ & & $x$ \\
\hline $\begin{array}{l}\text { Liu \& Kleinsasser } \\
\text { (2015) }\end{array}$ & $\begin{array}{l}\text { Language Learning } \\
\text { and Technology }\end{array}$ & & & $\mathrm{x}$ & & $\mathrm{x}$ \\
\hline Tai (2015) & $\begin{array}{l}\text { Language Learning } \\
\text { and Technology }\end{array}$ & & & $x$ & & $x$ \\
\hline $\begin{array}{l}\text { Cahyono et.al } \\
(2016)\end{array}$ & $\begin{array}{l}\text { International } \\
\text { Journal of English } \\
\text { Language Teaching }\end{array}$ & & & $x$ & & $x$ \\
\hline Chien (2016) & $\begin{array}{l}\text { International } \\
\text { Journal of } \\
\text { Technology- } \\
\text { Enhanced Language } \\
\text { Learning }\end{array}$ & $x$ & & & $x$ & \\
\hline Hsu (2017) & $\begin{array}{l}\text { Computer Assisted } \\
\text { Language Learning }\end{array}$ & & $\mathrm{x}$ & & & $x$ \\
\hline Tseng (2017) & $\begin{array}{l}\text { Computer Assisted } \\
\text { Language Learning }\end{array}$ & & & $\mathrm{x}$ & & $\mathrm{x}$ \\
\hline Turgut (2017) & Cogent Education & & & $x$ & $\mathrm{x}$ & \\
\hline $\begin{array}{l}\text { Bostancıglu \& } \\
\text { Handley (2018) }\end{array}$ & $\begin{array}{l}\text { Computer Assisted } \\
\text { Language Learning }\end{array}$ & & $\mathrm{x}$ & & & $x$ \\
\hline $\begin{array}{l}\text { Drajati, et al } \\
(2018)\end{array}$ & $\begin{array}{l}\text { Indonesian Journal } \\
\text { of Applied } \\
\text { Linguistics (IJAL) }\end{array}$ & & $x$ & & $x$ & \\
\hline $\begin{array}{l}\text { Tseng, et al } \\
\text { (2019) }\end{array}$ & $\begin{array}{l}\text { Computers \& } \\
\text { Education Journal }\end{array}$ & & $\mathrm{x}$ & & $x$ & \\
\hline Mei, et al. (2018) & $\begin{array}{l}\text { Journal of } \\
\text { Educational }\end{array}$ & $x$ & & & $x$ & \\
\hline
\end{tabular}




\begin{tabular}{|c|c|c|c|c|c|}
\hline & $\begin{array}{l}\text { Computing } \\
\text { Research }\end{array}$ & & & & \\
\hline $\begin{array}{l}\text { Chuang, et al. } \\
\text { (2018) }\end{array}$ & $\begin{array}{l}\text { The Asia Pacific } \\
\text { Education } \\
\text { Researcher }\end{array}$ & $\mathrm{x}$ & & & $\mathrm{x}$ \\
\hline Habibi et al. (2019) & $\begin{array}{l}\text { Education and } \\
\text { Information } \\
\text { Technologies }\end{array}$ & $\mathrm{x}$ & & $\mathrm{x}$ & \\
\hline Nazari et al. (2019) & Cogent Education & & $\mathrm{x}$ & $\mathrm{x}$ & $\mathrm{x}$ \\
\hline
\end{tabular}

There were 20 papers of TPACK in EFL context reviewed from 2015 to 2019. There was a high publication of TPACK in EFL context in 2015. In the journal of Computer Assisted Language Learning, the highest number of TPACK articles in EFL context was found. The findings reported by Chai et al. (2013) confirm that the highest number of TPACK publications is found in the journal of education technology. Mixed method was the most widely used approach followed by quantitative method that harmonizes Wu's findings (2013). Meanwhile, current empirical studies on TPACK in EFL still suffer from the limitation of research design. It is proven that the number of qualitative studies on TPACK is very limited. From the research papers reviewed about TPACK in EFL context, in-service teachers were more studied than preservice teachers in EFL context which differs from the findings of $W u$ (2013).

The implementation of TPACK in EFL context was discussed the most, followed by assessment tool design for TPACK and the effects of TPACK framework in EFL context. However, the sample size for these empirical studies is relatively small and typically has about hundreds of participants. There should be more large-scale of empirical studies. Furthermore, it is still unclear about the knowledge underpinning teachers' technology integration practices. So, more empirical studies should be conducted to fill the gap of the previous studies. According to the paper reviewed, selfreporting was mostly used approach to identify EFL teacher TPACK. It is proven that to examine TPACK, most of the researchers employed self-assessment with survey. According to Willermark (2017), one of the ways to identify teacher TPACK is through selfreporting.

\section{Self-Reporting}

Self-reporting was used to identify the teacher TPACK. Self-reporting was divided into three categories, namely general TPACK, specific TPACK, and experienced TPACK. General TPACK refers to circumstances in which teachers measure the TPACK they experience. For example, by rating statements reflecting various TPACK constructs, such as "I am good with technology". Specific TPACK requires situating TPACK within a specific context. It refers to circumstances where TPACK is defined by the selfreporting of teachers about how they should act in particular scenarios. Experienced TPACK refers to cases in which teachers report on the actual 
experiences of the implementation of teaching activities. The self-report on general TPACK knowledge represented an approach in which TPACK is studied exclusively as knowledge since it involves estimating knowledge as something stable that the person possesses despite the situation. Studying the particular TPACK represents a slight step towards considering TPACK as a competence as it requires situating the knowledge.

\section{General TPACK Knowledge}

The most commonly used approach to evaluating TPACK was self-assessment by surveys. Numerous instruments were built that applied various ways of operationalizing the TPACK construction. A survey developed by Schmidt (2009) was the most widely used survey and it was implemented in 7 articles. Participants were asked to rate the numerical statements on a Likert scale of 5 or 7 points where the 7 sub-scales of TPACK domains were examined. In the Schmidt survey, the participants had to answer 75 items of the seven TPACK domains. The second most used survey was "TPACK EFL survey" and it was applied in 3 articles. It was developed by Baser et al. (2016). There are 9 points of Likert scale with 39 items in this questionnaire. There are other survey instruments introduced by the researchers in EFL context. There was a combination work of TPACK survey from Koh et al. (2010) and Sahin (2011). They developed 7-point Likert scale with 42 statements about TPACK components. Chuang and Huang (2012) developed a 24-item survey to address data on participants' self-perceived CALL competency. Habibi (2019) developed a 38-item survey which is the combination of TPACK survey (Koh et al., 2010; Luik et al., 2018; Schmidt et al., 2009) and UICT (Aslan and Zhu, 2017). It was developed to explore if TPACK is valid model to explain Indonesian pre-service language teachers in their teaching practices.

\section{Specific TPACK Knowledge}

Tai (2015) explored the impact of CALL workshop for teachers by using TPACK-in-Action model. The model is part of TPACK designed by Mishra and Koehler (2006) and an approach of learning-by-doing (Chapelle \& Hegelheimer, 2004). It is used to understand how English teachers develop their CALL competency and adopt it in their teaching practices. The researcher employed 14 survey items which were divided into 2 dimensions. The dimension 1 is about Use of Technology Tools and the Internet for Teaching, while for the dimension II is about Use Cloud Computing for Student Interactions and Discussion. Participants were asked to rate the numerical statement on 5-point Likert scale, with 1 as "Strongly Disagree" and 5 as "Strongly Agree".

\section{Experienced TPACK}

Tseng (2015) explored how English teacher in elementary school using tablet to improve student engagement by adopting the framework of TPACK. Qualitative data were collected to explore teacher's TPACK, such as Facebook reflection posts, observation in the classroom, and interview. Then, data of Facebook reflection posts were triangulated with class observation and transcription of the interview. Cahyono 
et al. (2016) employed TPACK-oriented teaching practice course to improve the quality of EFL instructional designs and teaching practices. They designed a course in which in-service teachers were introduced to TPACK framework and they were assigned to create instructional designs using TPACK framework. The teachers were asked to teach their peers using the instructional designs they have created. At the end, they were given the questionnaire to explore the benefits of instructional design using TPACK framework to improve the quality of their instructional designs and teaching practices. Another research conducted by Tseng et al. (2015) explored how six pre-service teachers implemented various forms of TPACK through design thinking over 14 weeks course. The data about the implementation of TPACK were collected through postteaching discussions. It was recorded and transcribed verbatim.

\section{CONCLUSION}

The review reveals that researchers has mostly focused on examining teacher TPACK through self-reporting using general knowledge. Research trends show that mixed-method was mostly used in TPACK research to triangulate findings in EFL context. Furthermore, the trends also show that in-service teachers attracted more attention to explore teacher TPACK in EFL context. For the future research, another way to identify teacher TPACK is proposed and more instruments developed to support the identification of teacher TPACK competence in EFL context is suggested.

\section{REFERENCES}

Ansyari, M. F. (2015). Designing and evaluating a professional development programme for basic technology integration in English as a foreign language (EFL) classrooms. Australasian Journal of Educational Technology, 31(6). doi:10.14742/ajet.1675

Baser, D., Kopcha, T. J., \& Ozden, M. Y. (2015). Developing a technological pedagogical content knowledge (TPACK) assessment for preservice teachers learning to teach English as a foreign language. Computer Assissted Language Learning, 29(4), 749-764. doi: 10.1080/09588221.2015.1047456

Bostancioglu, A., \& Handley, Z. (2018). Developing and validating a questionnaire for evaluating the EFL "Total PACKage": Technological pedagogical content knowledge (TPACK) for English as foreign language (EFL). Computer Assisted Language Learning,31(5-6), 572598.

doi:10.1080/09588221.2017.14225 24

Cahyono, B. Y., Kurnianti, O, D., \& Mutiaraningrum, I. (2016). Indonesian EFL teachers' application of TPACK in in-service education teaching practices. International Journal of English Language Teaching, 4(5), 16-30.

Chai, C. S., Koh, J. H. L., \& Tsai, C.-C. (2013). A review of technological pedagogical

content knowledge. Educational Technology \& Society, 16(2), 3151.

doi:10.1177/0735633117713114 
Chien, W-. C. (2016). Investigating Taiwanese EFL digital natives' TPCK in teaching English to digital immigrants. International Journal of Technology Enhanced Learning, 8(2), 151-168.

Chuang, H.-H., Ho, C.-J., Weng, C.-Y., \& Liu, H.-C. (2018). High School Students' Perceptions of English Teachers' Knowledge in Technology-Supported Class Environments. The Asia-Pacific Education Researcher, 27(3), 197206. doi:10.1007/s40299-0180378-1

Clarke, D. J., Hollingsworth, H. (2002). Elaborating a model of teacher professional growth. Teaching and Teacher Education, 18(8), 947-967. doi:10.1016/s0742-051x(02)000537

Cox, S., \& Graham, C. R. (2009). Using an elaborated model of the TPACK framework to analyze and depict teacher knowledge. TechTrends, 53(5), 60-69. doi:10.1007/s11528009-0327-1

Drajati, N. A., Tan, L., Rochsantiningsih, D., \& Zainnuri, H. (2018). Investigating English language teachers in developing TPACK and multimodal literacy. Indonesian Journal of Applied Linguistics, 7(3), 575-582.

doi:10.17509/ijal.v7i3.9806

Graham, C. R. (2011). Theoretical considerations for understanding technological pedagogical content knowledge (TPACK). Computers \& Education, 57(3), 1953-1960. doi:10.1016/j.compedu.2011.04.01 0

Guerrero, S. (2013). Technological pedagogical content knowledge in the mathematics classroom. Journal of Digital Learning in Teacher Education, 26(4), 132-139

Habibi, A., Yusop, F. D., \& Razak, R. A. (2019). The role of TPACK in affecting pre-service language teachers' ICT integration during teaching practices: Indonesian context. Education and Information Technologies, 25(3), 1929-1949. doi:10.1007/s10639-019-10040-2

Hofer, M.J., \& Harris, J. (2012). TPACK research with inservice teachers: Where's the TCK ?

In C.D. Maddux \& D. Gibson (Eds.), Research highlights in technology and teacher education 2012 (pp. 31-36). Society for Information Technology and Teacher Education. Retrieved from https://www.learntechlib/p/41222

Hsu, L. (2017). Examining EFL teachers' technological pedagogical content knowledge and the adoption of mobile-assisted language learning: A partial least square approach. Computer Assisted Language Learning, 29(8), 1287-1297. doi:10.1080/09588221.2016.12780 24

Koehler, M. J., \& Mishra, P. (2005). What happens when teachers design educational technology? The development of technological pedagogical content knowledge. Journal of Educational Computing Research, 32(2), 131-152. doi:10.2190/0ew7-01wb-bkhl-qdyv

Koehler, M.J., \& Mishra, P. (2008). Introducing TPCK. In AACTE Committee on Innovation and Technology (Ed.), Handbook of technological pedagogical content knowledge (TPCK) for educators 
(pp. 3-29). New York, NY:

Routledge.

Koehler, M. J., Mishra, P., Kereluik, K., Shin, T. S., \& Graham, C. R. (2014). The technological pedagogical content knowledge framework. In J. M. Spector (Ed.), Handbook of research on educational communications and technology (pp. 101-111). New York, NY: Springer.

Jang, S. J., Chen, K. C. (2010). From PCK to TPACK: developing a transformative model for preservice science teachers. Journal of Science Education and Technology, 19(6), 553-564. doi:10.1007/s10956-010-9222-y

Lei, J. (2009). Digital natives as preservice teachers: what technology preparation is needed. Journal of Computing in Teacher Education, 25(3), 87-97. Retrieved from https://www.tandfonline.com/doi/ abs/10.1080/10402454.2009.1078 4615

Liu, M. H. (2015). Exploring EFL teachers' CALL knowledge and competencies: In service program perspectives. Language Learning \& Technology, 19(1), 119-138.

Mahdum. (2015). Technological pedagogical and content knowledge (TPACK) of English teachers in Pekanbaru, Riau, Indonesia. Mediteranian Journal of Social Sciences, 6(5), 168-176. doi: 10.5901/mjss.2015.v6n5s1p168

Mei, B., Brown, G. T. L., \& Teo, T. (2017). Toward an Understanding of Preservice English as a Foreign Language Teachers' Acceptance of Computer-Assisted Language Learning 2.0 in the People's
Republic of China. Journal of Educational Computing Research, 56(1), 74-104. doi:10.1177/0735633117700144

Mishra, P., \& Koehler, M. J. (2006). Technological pedagogical and content knowledge: A framework for teacher knowledge. Teachers College Record, 108(6), 1017-1054. Retrieved from https://asu.pure.elsevier.com/en/p ublications/technologicalpedagogical-content-knowledge-aframework-for-teach

Nazari, N., Nafissi, Z., Estaji, M., Marandi, S. S., \& Wang, S. (2019). Evaluating novice and experienced EFL teachers' perceived TPACK for their professional development. Cogent Education, 6(1). doi:10.1080/2331186x.2019.16320 10

Oz, Huseyin. (2015). Assessing preservice English as a foreign language teachers' technological pedagogical and content knowledge. International Education Studies, 8(5), 119-130. http://dx.doi.org/10.5539/ies.v8n5 p119.

Schrum, L., Thompson, A., Maddux, C., Sprague, D., Bull, G., Bell, L. (2007). Editorial: research on the effectiveness of technology in schools: the roles of pedagogy and content. Contemporary Issues in Technology and Teacher Education, $7(1)$, 456-460. Retrieved from https://new.citejournal.org/wpcontent/uploads/2016/04/v7i1editori al1.pdf

Shulman, L.S. (1986). Those who understand: Knowledge growth in teaching. Educational Researcher, 
Vol. 2 No. 2

December 2020

e- ISSN 2685 - 0559

p- ISSN 2684 - 673X

15(2), 4-14. doi: 10.3102/0013189X015002004

Selwyn, N. (2012). Making sense of young people, education, and digital technology: The role of sociological theory. Oxford Review of Education, 38(1), 81-96. doi: 10.1080/03054985.2011.577949

Tai, S.-J. D. (n.d.). From TPACK-in-Action Workshops to English Classrooms: CALL Competencies Developed and Adopted into Classroom Teaching. doi:10.31274/etd-180810-3577

Tseng, J. J. (2017). Exploring TPACK-SLA interface: insights from the computer-enhanced classroom. Computer Assisted Language Learning, 31(4), 390-412. doi:10.1080/09588221.2017.14123 24

Tseng, J. J., Cheng, Y. S., \& Yeh, H. N. (2019). How pre-service English teachers enact TPACK in the context of web-conferencing teaching: A design thinking approach. Computers \& Education, 128, 171-182. doi:10.1016/j.compedu.2018.09.02 2

Turgut, Y. (2017). Tracing preservice English language teachers' perceived TPACK in sophomore, junior, and senior levels. Cogent Education, $4(1)$. doi:10.1080/2331186x.2017.13686 12

Voogt, J., Fisser, P., Roblin, N. P., Tondeur, J., \& Van Braak, J. (2013). Technological pedagogical content knowledge - A review of the literature. Journal of Computer and Assisted Learning, 29(2), 109-121. Retrieved

from https://www.learntechlib.org/p/42 537/.

Wu, Y.-T., \& Wang, A. Y. (2015). Technological, Pedagogical, and Content Knowledge in Teaching English as a Foreign Language: Representation of Primary Teachers of English in Taiwan. The Asia-Pacific Education Researcher, 24(3), 525-533. doi:10.1007/s40299-015-0240-7

Wu, Y. T. (2013). Research trends in tec hnological pedagogical content kno wledge (TPACK) research: $A$ review of empirical studies published in sel ected journals from 2002 to 2011. British Journal of Educational Techn ology, 44(3), E73-E76. doi:10.1111 /j.1467-8535.2012.01349.x 